\title{
Fresh Produce Valuation in Portuguese Traditional Food Markets: Consumer Perspectives
}

J. Sampaio ${ }^{1}$, L.M. Cunha ${ }^{2,4}$, A.P. Moura ${ }^{3,4}$ and A. Rocha ${ }^{1,4, \text { a }}$

${ }^{1}$ Faculdade de Ciências da Nutrição e Alimentação, Universidade do Porto, Rua Dr. Roberto Frias, 4200-465 Porto, Portugal

${ }^{2}$ Faculdade de Ciências da Universidade do Porto, Campus Agrário de Vairão, Rua Padre Armando Quintas, 7, 4485-661 Vairão, Portugal

${ }^{3}$ Universidade Aberta, Rua do Ameal, 752, 4200 Porto, Delegação Porto, Portugal

${ }^{4}$ Associated Laboratory REQUIMTE, Campus Agrário de Vairão, Rua Padre Armando Quintas, 7, 4485-661 Vairão, Portugal

Keywords: consumer perspectives, fresh produce, traditional food markets

\begin{abstract}
In Portugal, traditional food markets have shown a decrease in popularity, mostly because of the growth of organized retailing and increased globalization. Attempts have been made to find what motivates consumers to purchase locally produced foods. The objective of this work was the characterization of consumers from Portuguese traditional food markets, and the identification of their attitudes and perceptions towards those markets. The final aim was to identify opportunities and challenges of traditional food markets' retailers. Interviews were conducted with consumers at traditional food markets from all over Portugal. One hundred forty-four consumers were asked about their shopping profile, reasons to visit the market, overall degree of satisfaction, as well as socio-economic characteristics. The most bought products on traditional food markets are fresh fruits and vegetables followed by fresh fish and flowers. The main reasons pointed out by consumers to visit these markets are produce freshness $(60 \%)$ price/quality relationship, i.e., a low price for a certain quality (34\%) and the price of traditional products $(34 \%)$. Moreover, results suggest an overall degree of satisfaction with traditional markets, showing that with an adequate communication strategy more consumers could be allured to them.
\end{abstract}

\section{INTRODUCTION}

There are two types of local markets: farmers markets and traditional food markets. The first are characterized by a direct relationship between producers/farmers and consumers and all products sold have been grown, reared, caught, brewed or processed by the stallholder (Archer et al., 2008), while the latter are characterized by their location in historical city centers, made up by small stalls often within a dedicated and permanent area, typically family-owned and operated.

Local markets are an integral part of the urban/farm linkage and have continued to rise in popularity, mostly because of growing consumer interest in obtaining fresh products directly from producers. Local markets allow consumers to have access to locally grown, fresh produce, and give farmers the opportunity to develop a personal relationship with their customers and to cultivate consumer loyalty. Farm products sold directly through local markets continue to be an important sales outlet for agricultural producers. Each consumer must choose where to shop and what to purchase once there (Hartman Group, 2008). We assume that consumer maximize their utility, at each purchase occasion, by choosing consumption levels of individual goods within a separable category of food products such as fresh produce (Thilmany et al., 2008).

A growing interest in local food products has been described by several authors who found that consumers prefer locally grown products, even when freshness is held constant, and they are willing to pay almost double for a product from a closer location

a adarocha@fcna.up.pt 
(Feagan et al., 2004). To maintain consumer trust and confidence and to grow demand, it is important for manufacturers, marketers and retailers to understand that quality markers, such as use of local ingredients and narratives of local production and origin, are factors that resonate most strongly with consumers when it comes to determining what is authentically local (Hartman Group, 2008).

According to Connell et al. (2008) 'good food' can be understood as a combination of seasonal fresh food, nutritional content, food safety, food grown or produced locally, animal welfare and appearance. Indeed the act of procurement is part of food choices where attention focuses on the values associated with where, and from whom food is obtained. Hence the phenomenon of producers (farmers) selling food products directly to end consumers and their interactions has gained much attention. For some people it might be held that 'good food' can only be purchased from a producer perhaps at the local market (Brown, 2002; Connell et al., 2008).

Connell et al. (2008) found that people who shop more often at local food markets have conceptions of 'good food' that are different from those of people who shop less often. Also, people who shop at local food markets more often take additional factors into consideration when purchasing food. Finally, consumers who usually buy at local food markets rate the 'local' factor as an important characteristic of a 'good food' compared to less frequent local shoppers. These findings suggest that buying at local markets and 'good food' choices are interconnected. Thus, a local market can be perceived as a place to buy 'good food' and as a means to express values associated with food choices.

Quality, freshness, and being locally produced are considered the most important factors for consumers buying at local market. A study by USDA (2006) highlighted the interaction between producers and consumers as the core element of the local market. Similarly, Feagan et al. (2004) found freshness, local farmer and community support, and social interaction to be significant motivations for consumers buying at local markets. Other characteristics associated with those who purchase local produce include farm background and membership in environmental groups (Thilmany et al., 2008).

Those who do not shop at local markets cite access issues as obstacles, such as distance from home and inconvenience of the market location. Attitudinal and behavioral characteristics generally are better predictors of local food buying behavior than are demographic characteristics (Kennedy, 2008; Lyon et al., 2008).

Most of the studies on local markets tend to rely on farmers markets while little has been done specifically with urban traditional food markets. The objective of this work was to characterize consumers from Portuguese traditional food markets, and to identify their attitudes and perceptions towards those markets. Another aim was to identify opportunities and challenges of traditional food markets' retailers.

\section{MATERIALS AND METHODS}

Face-to-face interviews were conducted with consumers visiting traditional food markets from ten different municipalities all over Portugal. Consumers were interviewed between December 2008 and February 2009. A convenience sample (Malhotra, 2007) was drawn, consisting of 144 consumers selected at random inside markets. Individuals were screened to exclude first-time shoppers. The questions asked covered shopping profile, reasons to visit the market and proposed improvements out of pre-defined choice lists, as well as the overall degree of satisfaction with a market and interviewees' socioeconomic details.

\section{RESULTS}

Of the 144 consumers, about $78 \%$ were female, with an average age of $52 \pm 15$ years (Table 1). Almost 60\% lived in urban areas this being explained by the fact that the majority of the markets are located in city centers. Although no data is available on demographics of Portuguese traditional market shoppers, results lead to the understanding that there was some oversampling of consumers with a high level of education, relatively high incomes and differentiated professional occupations. 
Over $60 \%$ of consumers visited the market at least once a week, those being considered as frequent consumers (Table 2). The most popular products purchased at traditional food markets (Fig. 1) are fresh fruits and vegetables (88 and $82 \%$, respectively) followed by fresh fish and flowers (38 and 37\%). The main reasons for consumers to visit traditional markets (Fig. 2) are produce freshness (58\%), price/quality relationship, corresponding to the relation that consumer establish between price and quality of products sold at the markets (32\%) and price of traditional food products, such as regional bread, typical cheeses (34\%). Major improvements proposed for such markets are related to the price of products $(39 \%)$, product display (35\%) and market safety and hygiene (28\%) (Fig. 3). Moreover, the results suggest an overall degree of satisfaction with the market, with over $70 \%$ of respondents considering themselves as highly or very highly satisfied with the market (Fig. 4).

\section{DISCUSSION}

The agro-food system in Portugal has undergone a deep transformation during the last three decades and the acceleration of technological innovation and economic globalization process are impelling a complex process of productive restructuration within all food system activities (Nueno, 2001). This process is exacerbated by the concentration of Portuguese food retailing brought about by the drive of efficiency in food production (Roland Berger, 2009). In fact, the arrival of the supermarket format has changed consumers shopping habits: consumers can get all their food shopping in a onestop shop which is often found outside main urban areas, at least for the largest areas (DH, 2001). However, most Western European countries have faced various food safety incidents (e.g., BSE, dioxin contamination), since the mid 1980s, that had led to increasing public unease about health and safety of modern methods of food production (Cunha and Moura, 2004; Kennedy, 2008). These are amplified by the media, making the public more aware that food can be potentially health threatening (Moura and Cunha, 2009). As a result, scares about a given food create adverse short-term effects on preferences and consumption of that particular food, which can more widely affect the overall effectiveness and efficiency of the food supply chain (Cunha et al., 2010). These attitudes tend to be reinforced by the absence of face-to-face contact between buyers and sellers during the process of food selection, leaving the burden of assessing product quality entirely in consumers' hands. Shopping under these circumstances is a stressful activity, while the lack of trust in agricultural and industrial methods of production and food quality gives rise to feelings of uncertainty and insecurity (Cunha and Moura, 2004).

In this context, traditional Portuguese food markets may be perceived by consumers as one way to reduce their anxiety. In fact, traditional Portuguese food markets are perceived by consumers as a good place for purchasing fresh foods. Moreover, consumers are able to find out as much information as they need to know about the product on sale and they may profit a more enjoyable and sociable shopping experience. Consumers consider that retailers are more friendly and able to build a trustworthy relationship, which they do not identify in supermarkets (unpublished data). These factors may explain why people like to attend traditional food markets, as they are very similar to other markets alternatives, such as farmers markets (La Trobbe, 2001). However, traditional Portuguese food markets have been in decline since the 1990s (Dias, 2001). Two main factors that are linked may explain this situation: those related to consumers and those related to suppliers. In fact, modern consumers are increasingly demanding for a wide variety of products, convenience food (they have no time to prepare meals from many different raw ingredients). In fact, convenience is a major concern in food purchases, particularly by members of urbanized societies (Moura and Cunha, 2005). Increasing number of women in the labor market, changing family structure and lifestyles (decreasing number of extended families and increasing number of households with single parents, working couples, and unassociated adults living together) reduced the chance to find an adult in the household with the time or energy to prepare meals. Consequently, the relative cost of time spent shopping is becoming much higher for the 
household. Furthermore, traditional Portuguese food markets, when compared with modern retailing, present reduced opening hours, poor parking spaces and accessibility, as partly inferred through data on Figure 3.

\section{CONCLUSIONS}

Fresh fruits and vegetables appear to be the main products bought at traditional markets in Portugal, to which consumers are mainly attracted because of the perceived produce freshness. Relatively higher prices may be a problem as many consumers perceive the price premiums they have to pay as a major cause of concern.

Portuguese consumers appear to have a positive attitude towards the evaluated food markets. Nevertheless, a decrease in the number of customers has been observed as the number of alternatives, such as supermarkets, increase.

Results from this work can help different stakeholders to focus their communication in a more efficient way, thus potentially attracting more costumers to the markets. By using appropriate marketing instruments more consumers may be motivated to attend traditional food markets since an increasing number of people value traditional and locally produced items as well as farm fresh produce more highly.

\section{Literature Cited}

Archer, G.P., Sánchez, J.G., Vignali, G. and Chaillot, A. 2008. Latent consumer's attitude to farmer'market in North West England. British Food Journal 105 (8):487-497.

Brown, A. 2002. Farmers market research 1940-2000: an inventory and review. American Journal of Alternative Agriculture 17(4):167-176.

Cachinho, H. 2002. O Comércio Retalhista em Portugal: Pós-Modernidade, Consumidores e Espaço, GEPE, Lisbon, Portugal.

Connell, D.J., Smithers, J. and Joseph, A. 2008. Farmers' markets and the 'good food' value chain: a preliminary study. Local Environment 13(3):169-185.

Cunha, L.M. and Moura, A.P. 2004. Conflicting demands of agricultural production and environment protection: consumers' perception on quality and safety of food. p.137157. In: W. Leal Filho (ed.), Ecological Agriculture and Food Production in Central and Eastern Europe - Risks Associated with Industrial Agriculture, Vol. 44. NATO Scientific Series, IOS.

Cunha, L.M., Moura, A.P., Lopes, Z., Santos, M.C. and Silva, I. 2010. Public perceptions of food-related hazards: an application to Portuguese consumers. British Food Journal 112(5). (in press)

DH. 2001. Anuário da Distribuição Portuguesa, Distribuição Hoje. APED, Lisbon, Portugal.

Dias, E.T. 2001. Mercados Municipais. Cadernos DGCC nº 13, DGCC. Lisbon, Portugal.

Feagan, R., Morris, D. and Krug, K. 2004. Niagara region farmers' markets: local food systems and sustainability considerations. Local Environment 9(3):235-254.

Hartman Group. 2008. Consumer Understanding of Buying Local. Hartbeat 27.

IEFP. 2008. Classificação nacional de profissões - CNP. http://www.iefp.pt/formacao/CNP/Paginas/CNP.aspx.

INCM. 2008. Decreto Lei no 246/2008 de 18 de Dezembro. Diário da República, $1^{a}$ série, $\mathrm{N}^{\mathrm{o}} 244$.

Kennedy, J. 2008. Segmentation of US consumers based on food safety attitudes. British Food Journal 110(7):601-705.

La Trobe, H. 2001. Farmers' markets: consuming local rural produce. International Journal of Consumer Studies 25(3):181-192.

Lyon, P., Collie, V., Kvarnbrink, E.B. and Colquhoun, A. 2008. Fresh food and producer sales: what do farmers' markets reveal about consumer perspectives? p.331-340. In: K. Hansen (ed.), Culinary Arts and Sciences VI: Global, National and Local Perspectives. Svein Larsen \& John Edwards.

Malhotra, N.K. 2007. Marketing Research: an Applied Orientation. 5th edition. Pearson International Edition, New Jersey, USA. 
Moura, A.P. and Cunha, L.M. 2005. Why consumers eat what they do: an approach to improve nutrition education and promote healthy eating. p.144-156. In: D. Doyle (ed.), Consumer Citizenship: Promoting New Responses, Taking Responsibility, Vol. 1. Forfatterne, Norway.

Moura, A.P. and Cunha, L.M. 2009. Understanding the Role of Printed Media in the Social Amplification of Food Risk During the New Millenium. p.144-155. In: A. Klein and W. Thoresen (eds.), Consumer Citizenship: Promoting New Responses, Making a Difference, Vol. 5. Fortatterne, Norway.

Nueno, J.L. 2001. Os consumidores e a alimentação no século XXI em Portugal. APED, Lisbon, Portugal.

Roland Berger. 2009. A Evolução da Concentração da Indústria e da Distribuição em Portugal: Principais Conclusões. APED, Lisbon, Portugal.

Thilmany, D., Bond, C.A. and Bond, J.K. 2008. Going local: exploring consumer behavior and motivations for direct food purchases. Amer. J. Agric. Econ. 90(5):13031309.

USDA, Agricultural Marketing Services. 2006. Farmers Markets Benefits. http://www.ams.usda.gov/AMSv1.0/ams.fetchTemplateData.do?template=TemplateM \&navID $=$ WholesaleandFarmersMarkets\&leftNav $=$ WholesaleandFarmersMarkets\&pa ge $=$ WFMWhoBenefits\&description=Who Benefits from Farmers Markets?\&acct=frmrdirmkt 


\section{Tables}

Table 1. Socio-economic characteristics of the sample $(n=144)$.

\begin{tabular}{|c|c|}
\hline Characteristics & $\%$ \\
\hline \multicolumn{2}{|l|}{ Gender } \\
\hline Male & 22.2 \\
\hline Female & 77.8 \\
\hline \multicolumn{2}{|l|}{ Age group (years) } \\
\hline 20 to 39 & 24.3 \\
\hline 40 to 59 & 40.3 \\
\hline$\geq 60$ & 35.4 \\
\hline \multicolumn{2}{|l|}{ Average \pm standard dev. $=51.4 \pm 14.9$} \\
\hline \multicolumn{2}{|l|}{ Marital status } \\
\hline Single & 9.0 \\
\hline Married/living as married & 70.2 \\
\hline Separated/divorced/widow & 20.8 \\
\hline \multicolumn{2}{|l|}{ Household dimension } \\
\hline 1 person & 18.8 \\
\hline 2 persons & 23.6 \\
\hline 3 persons & 27.8 \\
\hline $4+$ & 29.8 \\
\hline \multicolumn{2}{|l|}{ Maximum level of education } \\
\hline Primary education or less (up to age 9 years) & 28.5 \\
\hline General/vocational secondary education or less ( 10 to 18 years) & 41.0 \\
\hline University/polytechnic degree ( $>18$ years $)$ & 29.9 \\
\hline \multicolumn{2}{|l|}{ Professional occupation } \\
\hline OG 1 & 12.5 \\
\hline OG 2 & 10.4 \\
\hline OG 3 & 21.5 \\
\hline OG 4 & 11.1 \\
\hline OG 5 & 16.7 \\
\hline Unemployed & 24.3 \\
\hline \multicolumn{2}{|l|}{ Monthly net household income* } \\
\hline$<500 €$ & 16.7 \\
\hline 500 to $999 €$ & 22.2 \\
\hline 1,000 to $1,499 €$ & 18.8 \\
\hline 1,500 to $2,999 €$ & 24.3 \\
\hline$\geq 3,000 €$ & 13.9 \\
\hline \multicolumn{2}{|l|}{ Place of residence } \\
\hline Urban & 56.9 \\
\hline Rural & 18.1 \\
\hline Urban periphery & 23.6 \\
\hline
\end{tabular}

*2009 Gross National Minimum Wage was $450 €$ (INCM, 2008). OG-occupational groups according to IEFP, ranging from CEO's (OG1) to non-qualified workers (OG5) (IEFP, 2008). 
Table 2. Consumer's proximity to markets, means of transportation used and frequencies of visits.

\begin{tabular}{lc}
\hline Consumer relation with market & \% of consumers \\
\hline Distance of household to market & \\
$<2 \mathrm{~km}$ & 33.3 \\
{$[2,4[$} & 22.2 \\
{$[4,8[$} & 18.8 \\
$\geq 8$ & 24.3 \\
Means of transportation & \\
Own vehicle & 58.3 \\
Public transportation & 17.4 \\
By foot & 23.6 \\
Visit to the market & \\
Less than once a week & 21.5 \\
Once a week & 43.1 \\
More than once a week & 35.4 \\
\hline
\end{tabular}

\section{Figures}

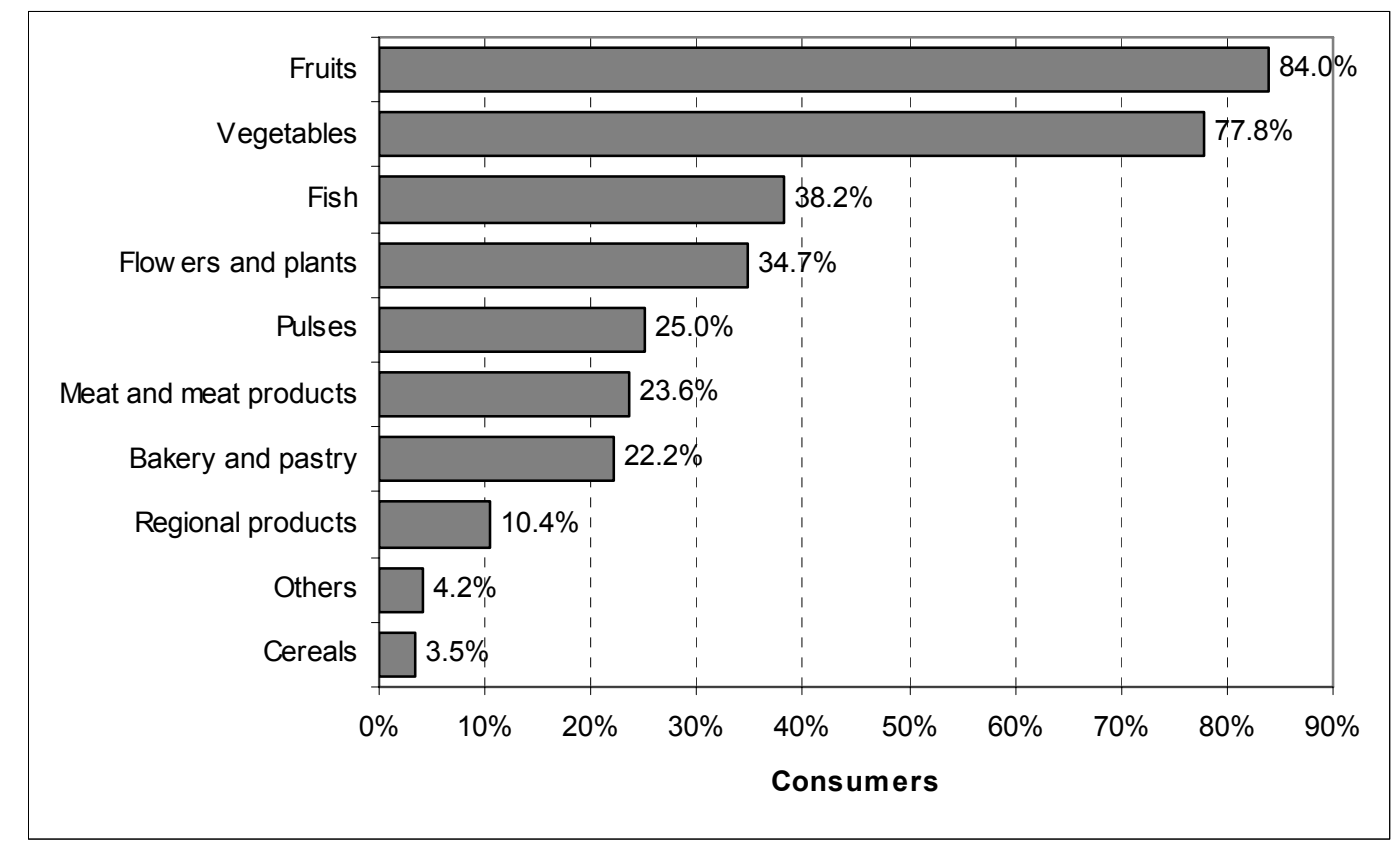

Fig. 1. Type of products usually bought at traditional markets. 


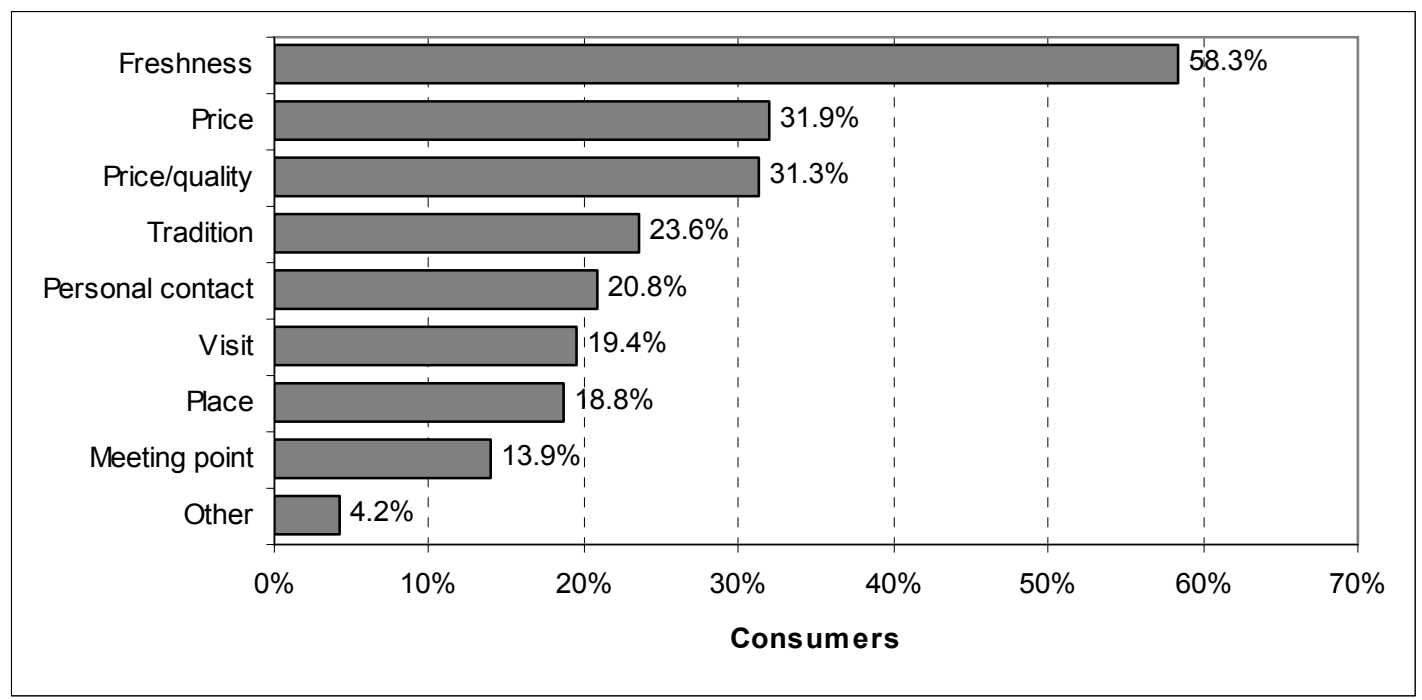

Fig. 2. Reasons to visit traditional markets.

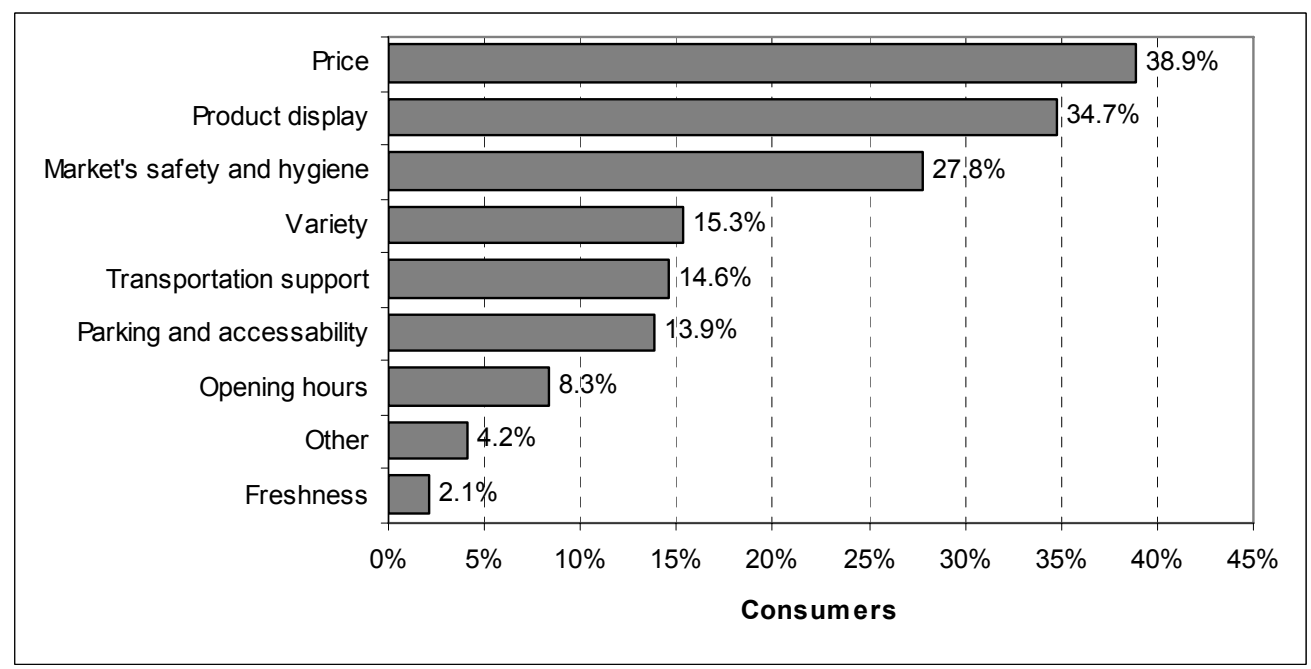

Fig. 3. Proposed market improvements chosen by consumers.

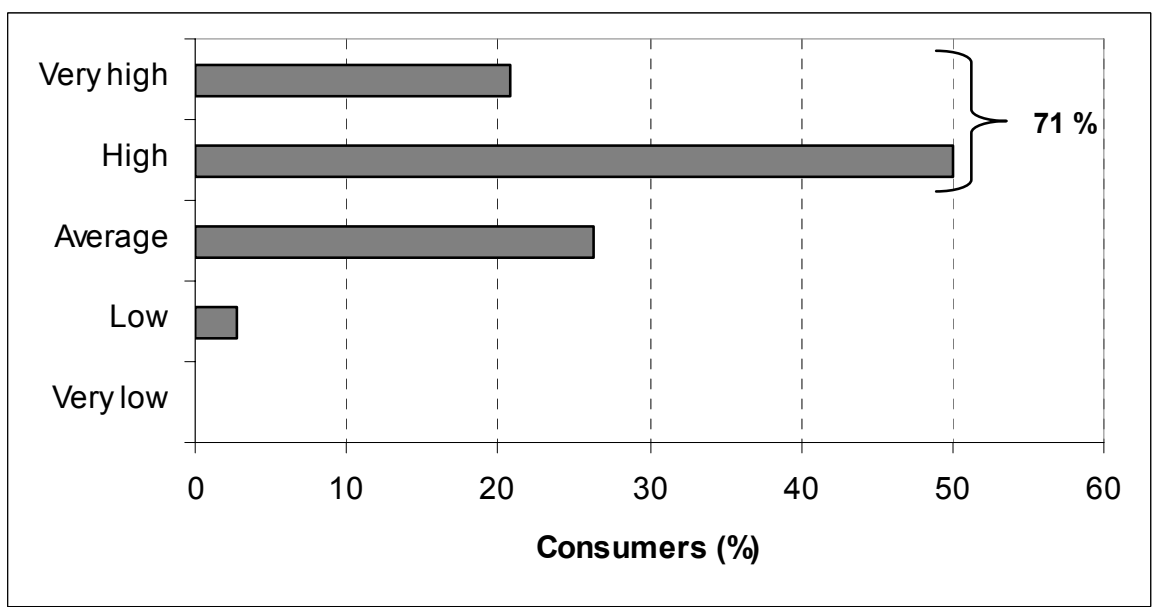

Fig. 4. Overall degree of satisfaction with traditional markets. 